\title{
Effective role of ascorbic acid as an alternative treatment of methemoglobinemia: A case report
}

\author{
Eman Abdelfath Mohammed, Salma Ibrahim Abdelkader, \\ Alaa Essam Mohmoud
}

\begin{abstract}
Introduction: Methemoglobinemia is a rare clinical disorder characterized by increase in the blood level of methemoglobin (MetHb) which leads to tissue hypoxia. Methemoglobinemia may be congenital, but acquired type is more common and occurs after exposure to oxidizing agents. Treatment of choice is methylene blue (MB). The side effects of $\mathrm{MB}$ restrict its usage in special conditions. Ascorbic acid is a good alternative drug with limited experience in methemoglobinemia. Case Report: Eight years old male patient presented with cyanosis after dapsone exposure and diagnosis of methemoglobinemia was confirmed. The patient was managed successfully with ascorbic acid. Conclusion: Ascorbic acid could be used as an alternative treatment for methemoglobinemia when methylene blue is not available or contraindicated.
\end{abstract}

Keywords: Ascorbic acid, Dapsone, Methemoglobinemia

Eman Abdelfath Mohammed ${ }^{1}$, Salma Ibrahim Abdelkader ${ }^{1}$, Alaa Essam Mohmoud ${ }^{2}$

Affiliations: ${ }^{1}$ Lecturer, Poison control center- Forensic Medicine and Clinical Toxicology, Faculty of Medicine, Ain Shams University, Cairo, Egypt; ${ }^{2}$ Assistant Lecturer, Poison control center- Forensic Medicine and Clinical Toxicology, Faculty of Medicine, Ain Shams University, Cairo, Egypt.

Corresponding Author: Salma Ibrahim Abdelkader, Department of Forensic Medicine and Clinical Toxicology, Faculty of Medicine, Ain Shams University, Poison Control Center, Cairo Egypt, 11517; Email: Dr_salmibr@yahoo.com

Received: 14 February 2018

Accepted: 27 June 2018

Published: 24 July 2018

\section{How to cite this article}

Mohammed EA, Abdelkader SI, Mohmoud AE. Effective role of ascorbic acid as an alternative treatment of methemoglobinemia: A case report. Int J Case Rep Images 2018;9:100941Zo1EM2018.

Article ID: 100941Zo1EM2018

$* * * * * * * * *$

doi: 10.5348/100941Zo1EM2018CR

\section{INTRODUCTION}

Methemoglobinemia is a medical emergency requiring immediate treatment. Methemoglobinemia is a condition in which iron atom in hemoglobin is transformed form a ferrous $\left(\mathrm{Fe}^{2+}\right)$ state to a ferric $\left(\mathrm{Fe}^{3+}\right)$ state due to effect of oxidizing agent exposure. Thus, beside the inability of methemoglobin (MetHb) to carry $\mathrm{O}_{2}$, MetHb shifts the oxygen - hemoglobin dissociation curve to the left, hindering the release of $\mathrm{O}_{2}$ to the tissues [1]. There are many drugs and toxins such as nitrate, dapsone, prilocaine, antimalarial drugs and sulphonamides responsible for acquired methemoglobinemia [2]. Methylene blue (MB) is considered the commonest and the usual treatment of methemoglobinemia which may lead to serious complications and also it is contraindicated in some patients like those with glucose-6-phosphate dehydrogenase (G6PD) deficiency [3]. In this case report, we presented a child with methemoglobinemia induced by dapsone and the patient was treated and improved with ascorbic acid to highlight its effectiveness as an alternative treatment.

\section{CASE REPORT}

An eight years old male child presented with unexplained cyanosis suspecting methemoglobinemia. 


\section{EDORIUM Journals}

The mother gave history that her child was kept on dapsone since three days (50 mg PO qDay) and last dose was four hours before presentation. The drug was prescribed by child's doctor for treatment of skin condition. Twenty four hours after starting dapsone treatment the mother noticed bluish discoloration peripherally which intensified and involved lips on the $3^{\text {rd }}$ day of treatment and there was an attack of vomiting. The child was diabetic and kept on insulin but didn't have any cardiac disease or asthmatic episodes. There was no history suggestive of foreign body inhalation or glucose6-phosphate dehydrogenase (G6PD) deficiency.

Examination of the child revealed central and peripheral cyanosis. The patient was conscious, alert (Galscow Coma Scale (GCS) 15/15), pulse rate was of 112/ minute (min), regular rhythm, systolic blood pressure of $100 \mathrm{mmHg}$, respiratory rate of $24 / \mathrm{min}$, and body temperature of $37^{\circ} \mathrm{c}$ axillary. Oxygen saturation with pulse oximetry was $78 \%$ on room air. The rest of the physical examination was normal.

Blood collected for laboratory investigations was chocolate brown in color. Laboratory results revealed hemoglobin $(11.7 \mathrm{~g} / \mathrm{dl})$ and total leukocyte count $\left(6.5 \times 10^{3} / \mathrm{mm}^{3}\right)$, Platelets count $(305000 / \mathrm{cmm})$. Serum bilirubin was $1.9 \mathrm{mg} \%$, blood urea, creatinine and serum electrolytes were within normal limits. Arterial blood gas analysis was $\left(\mathrm{pH}-7.36, \mathrm{PCO}_{2}-33.5 \mathrm{mmHg}, \mathrm{PO}_{2}-\right.$ 65.1mmHg, $\mathrm{HCO}_{3}-23.8 \mathrm{mEq} / 1$ and $\left.\mathrm{SpO}_{2} \%-92.3 \%\right)$. The methemoglobin level was $24.8 \%$. There was saturation gap between $\mathrm{SpO}_{2}$ in $\mathrm{ABG}$ and pulse oximetry. The investigations are presented in (Table 1).

In view of history of dapsone exposure, cyanosis, chocolate color of blood and the saturation gap, a clinical diagnosis of dapsone induced methemoglobinemia was made and was confirmed by MetHb level.

Table 1: Laboratory results follow up

\begin{tabular}{lcc}
$\begin{array}{l}\text { Laboratory } \\
\text { investigation }\end{array}$ & On admission & On discharge \\
\hline $\mathrm{pH}$ & $7 \cdot 36$ & $7 \cdot 33$ \\
$\mathrm{PCO}_{2}(\mathrm{mmHg})$ & 33.5 & 48 \\
$\mathrm{PO}_{2}(\mathrm{mmHg})$ & 65.1 & 70 \\
$\mathrm{O}$ sat. \% & 92.3 & 90 \\
$\mathrm{Met} \mathrm{Hb} \%$ & 24.8 & 1.9 \\
$\mathrm{Na}(\mathrm{mEq} / \mathrm{l})$ & 133 & 135 \\
$\mathrm{~K}(\mathrm{mEq} / \mathrm{l})$ & 4.2 & 5.3 \\
$\mathrm{Hb}$ g/dl & 11 & 10.8 \\
$\mathrm{PLT} / \mathrm{mm}^{3}$ & 305 & 275 \\
$\mathrm{TLC} / \mathrm{mm}^{3}$ & 6.5 & 8 \\
\hline
\end{tabular}

Abbreviations: $\mathrm{pH}$ : negative log of hydrogen ion, $\mathrm{PCO}_{2}$ : Partial pressure of carbon dioxide, $\mathrm{PO}_{2}$ : patial pressure of oxygen, sat: saturation, MetHb: methemoglobin, Hb: hemoglobin, PLT: platelet count. TLC: total leukocyte count.
After confirming diagnosis, dapsone was stopped and the child was kept on oxygen inhalation by nasal prong, while on oxygen, the saturation only raised to $83 \%$.Multiple dose activated charcoal $1 \mathrm{~g} / \mathrm{kg}$ was given orally to the child, methylene blue was not available, thus slow intravenous administration of $1 \mathrm{gm}$ ascorbic acid was started . Injection ascorbic acid was continued as $1 \mathrm{gm} / 4 \mathrm{hs}$ (for 8 doses), no side effects occurred. The child showed signs of improvement, saturation gap and cyanosis disappeared, MetHb level was repeated after six hours of ascorbic acid therapy, day two and day three of admission which was $12.6 \%, 5.7 \%$ and $1.9 \%$ respectively, indicating successful therapy with ascorbic acid. The child was discharged with full recovery on the third day of admission.

\section{DISCUSSION}

Methemoglobinemia is a life-threatening condition; there is infrequent data on this condition in Africa [1]. $\mathrm{MetHb}$ is the oxidized form of hemoglobin that is unable to bind oxygen and also shift oxygen dissociation curve to the left, thus tissue oxygenation decreased resulting in cyanosis [3].

Toxic methemoglobinemia results from various drugs and toxins with oxidizing effects. The most common agents include: Nitroglycerine, dapsone, sulfonamides, phenacetin, and local anesthetics [2].

Methemoglobinemia in the present case was developed after therapeutic dose of dapsone. Dapsone is commonly used in treatment of leprosy but its use has expanded into the treatment of many skin diseases [4]. Methemoglobinemia associated with dapsone commonly as an adverse effect of the drug like patients use dapsone for pseudomonas jiroveci pneumonia prophylaxis in stem cell transplantation $[5,6]$.

Methemoglobinemia diagnosis is difficult and should be suspected in patient with unexplained cyanosis and low saturation on pulse oxymetry not responding to oxygen in addition to the saturation gap between arterial blood gas analysis and pulse oximetry which help in the diagnosis when MetHb level is not available [1, 6]. These were the clinical features of the present case, and the diagnosis was confirmed by MetHb level assessment.

The clinical picture of methemoglobinemia depends on the methemoglobin level in the blood. Cyanosis starts with MetHb around 15\%, the chocolate brown blood appear with level 15-30\%. Dyspnea develops between 30-50\%. Severe manifestations as metabolic acidosis, arrhythmias, coma and convulsions occur at 50-70\%. Methemoglobin levels of $70 \%$ or more may be fatal, however mortality with lower level of MetHb(10.8\%) have also been reported [1].

Dapsone induces a continuing oxidative stress due to the long half-life, thus serial measurements of methemoglobin levels should be done [4]. Initial management of acquired methemoglobinemia inculdes 


\section{EDORIUM Journals}

Int J Case Rep Images 2018;9:100941Z01EM2018.

www.ijcasereportsandimages.com

Table 2: Case reports of methemoglobinemia treated with ascorbic acid

\begin{tabular}{|c|c|c|c|c|c|c|c|}
\hline Author & Age & $\begin{array}{l}\text { Causative } \\
\text { agent }\end{array}$ & $\begin{array}{l}\text { Initial } \\
\text { MetHb } \\
(\%)\end{array}$ & $\begin{array}{l}\text { Indication of } \\
\text { ascorbic acid }\end{array}$ & $\begin{array}{l}\text { Dose of } \\
\text { Ascorbic } \\
\text { acid }\end{array}$ & $\begin{array}{l}\text { Duration } \\
\text { of therapy } \\
\text { (hours) }\end{array}$ & $\begin{array}{l}\text { Other } \\
\text { specific } \\
\text { treatment }\end{array}$ \\
\hline Deo P. et al. [8] & 15 years & Napthalene ball & $25 \cdot 3$ & G6PD deficiency & $\begin{array}{c}0.5 \text { gm q } 12 \\
\text { hs (16 doses) }\end{array}$ & 192 & No \\
\hline $\begin{array}{l}\text { Reeves D. et al. } \\
\text { [9] }\end{array}$ & 46 years & Rasburicase & 14.5 & G6PD deficiency & $\begin{array}{l}5 \text { gm q } 6 \text { hs } \\
\text { (6 doses) }\end{array}$ & 36 & No \\
\hline Sahu K. et al. [10] & 45 years & Dapsone & 18.3 & Unavailable MB & $\begin{array}{l}1 \text { gm q } 12 \text { hs } \\
\text { (14 doses) }\end{array}$ & 168 & No \\
\hline Tokar I. et al. [2] & 34 years & Dapsone & 28.2 & Unavailable MB & $2 \mathrm{~g}(1$ dose $)$ & 1 & $\begin{array}{l}\text { Hyperbaric } \\
\text { oxygen, MB }\end{array}$ \\
\hline Topal H. et al. [7] & 70 days & local prilocaine & 24.5 & Unavailable MB & $\begin{array}{l}300 \mathrm{mg}(24 \\
\text { hs infusion) }\end{array}$ & 24 & No \\
\hline Current case & 8 years & Dapsone & 24.8 & Unavailable MB & $\begin{array}{c}\text { 1gm q } 4 \text { hs }(8 \\
\text { doses }\end{array}$ & 32 & No \\
\hline
\end{tabular}

Abbreviations: MB: Methylene blue, hs: hours, G6PD: glucose-6-phosphate dehydrogenase

identification and discontinuation of the offending agent and increasing tissue oxygenation by administration of reducing agent as $\mathrm{MB}$ and ascorbic acid [1].

Methylene blue is the usual treatment for methemoglobinemia, however methylene blue is potentially hazardous. Methylene blue can conversely cause methemoglobinemia in high doses by its oxidant effect and induce hemolysis in cases of G6PD deficiency in addition to turning the skin blue, which is the commonest side effect $[2,7]$. Therefore, alternative treatments are required. Ascorbic acid is a strong reducing agent that takes part in many oxidation-reduction reactions, so ascorbic acid directly reduce methemoglobin and is proven to treat cyanosis [3]. In many case reports, ascorbic acid was used successfully in treatment of methemoglobinemia with different doses and durations as discussed in Table 2 [8-10]. In the present case, a decline of $12.2 \%$ in methemoglobin levels after six hours of administration of $2 \mathrm{~g}$ ascorbic acid was noticed.

On contrary, other study reported that acquired methemoglobinemia does not respond to ascorbic acid, because its capacity to reduce MetHb is much inferior to that of endogenous enzymatic systems [11]. However, failure of ascorbic acid in treatment of methemoglobinemia could be attributed to using lower doses or shorter durations of therapy [2].

The use of activated charcoal improve clearance rates of methemoglobin at lower concentrations of methylene blue, also multiple dose activated charcoal enhance elimination of dapsone by interrupting its enterohepatic circulation. The child was given multiple doses of activated charcoal in the present study $[2,5]$.

\section{CONCLUSION}

Although, there is an experience with the use of methylene blue as specific antidote in treatment of methemoglobinemia, ascorbic acid should be used as an alternative treatment when methylene blue is not available or contraindicated. Successful management of the present case highlight the importance of ascorbic acid as effective, cheap, and easily available alternative with no side effects. Dapsone has a long half-life and undergo enterohepatic circulation so may cause recurrence of methemoglobinemia,thus multiple dose activated charcoal should be given. Dapsone may induce life-threatening methemoglobinemia so restriction of its expanded use is recommended.

\section{REFERENCES}

1. Nabukeera-Barungi N, Mworozi E. Sudden onset methaemoglobinaemia in a previously well Ugandan child: A case report and literature review. Pan Afr Med J 2012;11:49.

2. Toker I, Yesilaras M, Tur FC, Toktas R. Methemoglobinemia caused by dapsone overdose: Which treatment is best? Turk J Emerg Med 2016 Mar 9;15(4):182-4.

3. Atyabi N, Yasini SP, Jalali SM, Shaygan H. Antioxidant effect of different vitamins on methemoglobin production: An in vitro study. Vet Res Forum 2012 Spring;3(2):97-101.

4. Agrawal A, Pandya S, Shrivastava J. Ascorbic acid as an effective alternative for treatment of dapsone poisoning in a child: A case report. Indian $\mathrm{J}$ case reports 2017;3(2):85-7.

5. Burke P, Jahangir K, Kolber MR. Dapsone-induced methemoglobinemia: Case of the blue lady. Can Fam Physician 2013 Sep;59(9):958-61.

6. Sangiolo D, Storer B, Nash R, et al. Toxicity and efficacy of daily dapsone as Pneumocystis jiroveci prophylaxis after hematopoietic stem cell transplantation: A casecontrol study. Biol Blood Marrow Transplant 2005 Jul;11(7):521-9.

7. Topal H, Topal Y. Toxic methemoglobinemia treated with ascorbic acid: Case report. Iran Red Crescent Med J 2013;15(12):e12718. 
8. Deo P, Sahu KK, Dhibar DP, Varma SC. Naphthalene ball poisoning: A rare cause of acquired methaemoglobinaemia. BMJ Case Rep 2016 May 25;2016.

9. Reeves DJ, Saum LM, Birhiray R. I.V. ascorbic acid for treatment of apparent rasburicase-induced methemoglobinemia in a patient with acute kidney injury and assumed glucose-6-phosphate dehydrogenase deficiency. Am J Health Syst Pharm 2016 May 1;73(9):e238-42.

10. Sahu KK, Dhibar DP, Gautam A, Kumar Y, Varma SC. Role of ascorbic acid in the treatment of methemoglobinemia. Turk J Emerg Med 2016 Aug 5;16(3):119-20.

11. do Nascimento TS, Pereira RO, de Mello HL, Costa J. Methemoglobinemia: From diagnosis to treatment. [Article in Portuguese]. Rev Bras Anestesiol 2008 Nov-Dec;58(6):651-64.

$* * * * * * * * *$

\section{Author Contributions}

Eman Abdelfath Mohammed - Analysis and interpretation of data, Revising it critically for important intellectual content, Final approval of the version to be published

Salma Ibrahim Abdelkader - Substantial contributions to conception and design, Acquisition of data, Drafting the article, Critical revision of the article, Final approval of the version to be published
Alaa Essam Mohmoud - Acquisition of data, Revising it critically for important intellectual content, Final approval of the version to be published

\section{Guarantor of Submission}

The corresponding author is the guarantor of submission.

\section{Source of Support}

None.

\section{Consent Statement}

Written informed consent was obtained from the patient for publication of this case report.

\section{Conflict of Interest}

Authors declare no conflict of interest.

\section{Copyright}

(C) 2018 Eman Abdelfath Mohammed et al. This article is distributed under the terms of Creative Commons Attribution License which permits unrestricted use, distribution and reproduction in any medium provided the original author(s) and original publisher are properly credited. Please see the copyright policy on the journal website for more information.
Access full text article on other devices

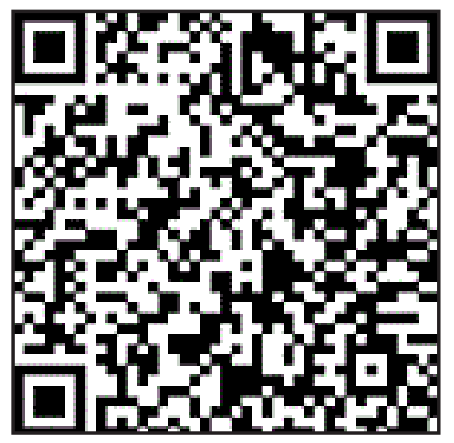

Access PDF of article on other devices

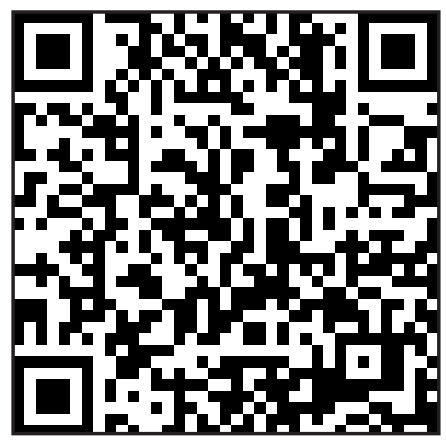

